\title{
Responding to the COVID-19 crisis: the rapid turn toward digital business models
}

\author{
Charlotta Kronblad \\ Department of Technology Management and Economics, \\ Chalmers University of Technology, Gothenburg, Sweden, and \\ Johanna Envall Pregmark \\ Department of Technology Management and Economics, \\ Chalmers University of Technology, Gothenburg, Sweden and IMIT, \\ The Institute for Managment of Innovation and Technology, Gothenburg, Sweden
}

Responding to the COVID-19 crisis

\begin{abstract}
Purpose - The effects of the spread of COVID-19 across the world are devastating, both from a health and an economic perspective. However, we also see encouraging examples of collaborative and innovative initiatives, in society and in organizations. The purpose of this paper is to focus on initiatives related to digital business model innovation. The authors explore how organizational characteristics provide a variety of opportunities for digital responses to the COVID-19 pandemic and discuss the potential consequences for the speed of digital transformation in organizations and society.

Design/methodology/approach - In this paper, the authors analyze how organizations attempt to mitigate the negative effects of fighting COVID-19 using digital business model responses. The authors draw on a qualitative study where they have collected data from the retail and service industries. They have analyzed the data in relation to theory to better understand this ongoing phenomenon.

Findings - The authors have identified four categories of organizations (crisispreneurs, accelerators, endurers and thrivers). Each category faces different challenges and shows a different intensity in their digital transformation. The authors propose that the rapid turn toward digital business models will have enduring effects, as organizations have gained transformational capabilities that will remain, and that the digital trajectory has, as a result, changed forever.

Originality/value - The findings in this paper point toward new challenges for leaders and policymakers in terms of how to support initiatives and meet the needs of different categories of organizations while simultaneously being conscious of the potential societal effects of this rapid digital shift. The authors hope that this paper can be of value for managing this shock and learning how to adapt for the future taking certain aspects of current business models as the departure point.
\end{abstract}

Keywords Digital transformation, Digital business models, COVID-19, Societal effects

Paper type Research paper

\section{Introduction}

People around the globe are currently fighting COVID-19. Apart from the obvious health consequences, diminishing stock market values, general recession and increasing

(C) Charlotta Kronblad and Johanna Envall Pregmark. Published by Emerald Publishing Limited. This article is published under the Creative Commons Attribution (CC BY 4.0) licence. Anyone may reproduce, distribute, translate and create derivative works of this article (for both commercial and non-commercial purposes), subject to full attribution to the original publication and authors. The full terms of this licence may be seen at http://creativecommons.org/licences/by/4.0/legalcode
Received 21 October 2020 Revised 18 December 2020 Accepted 17 January 2021 
unemployment are having devastating effects on the world's economies. The closing of borders has also affected the structure (production, supply chains, logistics and cross-border employment) of most multinational companies. The global economy, with its free trade areas and collaboration, has been breaking up and has seemingly been followed by the building of more nationalistic economies. What we have experienced during 2020 is incontestably a major transformation that challenges what we have previously thought to be true about our economy and market conditions. This makes it necessary for us to consider new ways to manage our organizations, and ourselves, to find a way out of the crisis.

One way to do this is to consider the opportunities in another of the largest transformations of our times: digitalization (Kronblad, 2020; Kronblad and Pregmark, 2019; Pasmore et al., 2019; Pasmore, 2015). Where COVID-19 closes borders and stops the movement of people and goods, digitalization opens up a solution space by providing immaterial movement of communication and services within instant global reach. Entrepreneurial initiatives (Fredberg and Pregmark, 2018), innovation (O'Connor, 2008) and digital innovation management (Nambisan et al., 2017) are crucial for organizations in times of change and can become powerful tools to overcome current COVID-19 effects, which has also been noted in recent research connecting responses to COVID-19 and opportunities for innovation (Dahlander and Wallin, 2020; Kronblad and Pregmark, 2021, forthcoming). Recent research has also pointed to an increased speed in the digital transformation of work as a result of COVID-19 (Kudyba, 2020; Leonardi, 2020).

In this paper, we to set out to discuss how digitalization and digital business models (Osterwalder, 2011; Teece and Linden, 2017) in the service industry and in retail can provide solutions to the current challenges induced by COVID-19. We ask what do innovative digital responses to the COVID-19 crisis look like among different organizations, if digital responses are equally viable for all types of organizations, and if the responses will affect the trajectory of the general digital transformation moving forward. We draw upon a qualitative, explorative interview study, which is complemented by notes from six global virtual seminars on the topic of COVID-19 and digital transformation. In addition, data have been collected from newspapers, digital press and press releases.

We can see that digital responses are commonly used to combat the COVID-19 crisis, but that organizations do this in different ways. In our findings, we have identified four categories of organizations, each with different responses to the effects of COVID-19. The identification is based on organizational characteristics and the opportunities and challenges digitalization poses for them. This contributes to an ongoing scholarly discussion of digital transformation and business model innovation and shows that materiality/immateriality aspects of current business models enable different responses to COVID-19 distress. We also discuss how the rapid turn toward digital models is re-shaping the trajectory of the digital transformation (Kronblad and Pregmark, 2019; Berman, 2012; Moore and Tambini, 2018) and reason around the effects and consequences for the different categories of organization. This contributes to the discussion about which factors influence a successful digital transformation (Kudyba, 2020; Dahlander and Wallin, 2020), and the larger societal discussion on how to manage challenges in the future of work. We end this discussion by calling on scholars and practitioners to engage in further research and discussion on these topics, as we see that there are potentially damaging consequences that need to be addressed, whereas there is also a need to support the positive impacts of the rapid shift toward digital business models.

\section{Theoretical frame}

To understand current business model responses to COVID-19, and how the digital transformation trajectory in society can change moving forward, we ground our thinking in 
a number of theoretical fields. First, we discuss the basis of a digital business model and outline differences in prerequisites for digital value creation. This is followed by a section on organizational transformation in general and digital transformation in particular, where we also address the effects of technology shifts on society.

Responding to the COVID-19 crisis

\section{Uneven landscape for digital value creation}

Some industries and some organizations were already largely digital prior to COVID-19, in that major parts of their business models had already been digitalized (Moore and Tambini, 2018; Remane et al., 2017). In times of social distancing and quarantine, these organizations that already have digital business models are primed for success. The booming on-line entertainment industry with on-line gaming, e-sports, e-gambling, streaming services for music, movies and TV-shows, apps, etc. is one example. Further examples come from organizations that provide global platforms for digital communication and social media. Their services span national borders and enable social activities despite physical quarantining. Digital organizations such as Google and Facebook (Moore and Tambini, 2018) have been enjoying growing markets and increasing demand, and their value creation and capture can continue within the scope of existing business models, relatively unaffected by COVID-19. In fact, these organizations may even see increasing demand owing to the increasing number of people in quarantine and an increased global desire for news, on-line shopping, etc. Consequently, digital organizations can continue to build value throughout the pandemic without making major changes. It is noteworthy that production within these digital organizations is relatively unaffected by the crisis, as they are primed for employees working remotely from home, using personal computers with virtual workspaces and digital tools for meetings and collaborations.

Although these digital organizations were already suited for the new - temporary world built on social distancing and quarantine, most organizations are rooted in materiality. Although many organizations have increased their basic digital capabilities, such as handling workflows working on remote (Hadden et al., 2020; Leonardi, 2020), large parts of their business models are based on physical products or on services that must be consumed and enjoyed in a physical place. Consider, for example, a hotel, where consumption (enjoying an overnight stay) is restricted to the physical place where the service (the overnight stay) is provided. The core of the business model in these organizations, their value proposition (Osterwalder, 2011), is hard to digitalize. Such organizations are clearly negatively impacted by COVID-19. However, they still need to act to survive. Despite the innate challenge of digitalizing organizations that have these material elements at the core of their business models, they still need to make fundamental changes and adapt quickly to the new reality (on top of being supported by new policies, etc.) for their mere survival. These organizations need to consider digital business model innovation (Nambisan et al., 2017) and think creatively about how to address consumer needs in new digital ways and how to shift production toward digital ways of working. In addition, organizations need to consider that digital readiness varies based on the differences in their customers and users (Iivari et al., 2020). Hence, organizations need to be inventive in their turn toward digital activities. In addition, turning to digital activities, digital processes, and business models requires an organization to embark on a change journey, which is often more easily said than done (Kotter, 2008; Beckhard and Harris, 1987).

Thus, we see that organizations are suited in different ways for different responses to COVID-19, and whether their current business model bases value on material or immaterial components is a major indicator of what responses are viable for them. 
Organizational change and transformation are well-investigated topics (Kotter, 2008; Pasmore, 2015). Traditional models for change often present change as a planned process (Kotter, 2008; Beckhard and Harris, 1987). More recent literature leans more toward discussing change as dependent on entrepreneurial initiatives and innovative work (Shibata et al., 2019; Kodama and Shibata, 2014; O'Connor, 2008; Fredberg and Pregmark, 2018; Bartunek and Woodman, 2014), where capability building, learning and iterative processes are important (Worley and Mohrman, 2016; Pasmore, 2015). Most literature agrees that there needs to be a clear motivation to change - such as a perceived threat (Kotter, 2008) and/or a meaningful aspiration (Fredberg and Pregmark, 2016, 2018).

Technology has played a vital part in shaping society and societal progression throughout history. This has been well documented through paradigm shifts in technology, valid long before the current digital transformation (Rogers, 1962; Utterback and Abernathy, 1975). New technology has been a driving force in the previous industrial shifts as the diffusion of new technology - seen as both opportunities and threats - has shaped society, the economy, the labor market and the market. Digitalization differs, however, from previous industrial shifts in that it entails the use of several new technologies that, in combination, constitute a more profound shift than ever before. The pace of change is also faster and the leaps are more radical (Reeves and Deimler, 2011). Digital transformation has even been discussed as a special kind of transformation (Fitzgerald et al, 2014; Ross et al., 2017; Kronblad and Pregmark, 2019) and many scholars argue that digital transformation is connected to a fundamental shift in reaching a competitive advantage and that it considers internal, external and holistic firm dimensions (Reis et al., 2018; Kaufman and Horton, 2015). Thus, digital transformation can be seen as the use of technologies to impact three dimensions: externally, with a focus on digital enhancing of the customer experience and the value proposition; internally, shaping operations, organizational structures and work processes; and holistically, where the whole organizational system is affected, leading to entirely new business models (Kaufman and Horton, 2015; Schuchmann and Seufert, 2015; Hess et al., 2016).

Whereas digital technologies were first introduced in manufacturing industries to make production more efficient, we currently see more broad changes where service industries are starting to change and where consumption patterns and the mindsets of workers and consumers are changing. Brynjolfsson and McAfee (2014) claim that we have entered into a Second Machine age, in which workers in intellectual industries are increasingly being replaced by technology (following the First Machine age, in which manual workers in manufacturing and agriculture were replaced by machines). In times of rapidly advancing artificial intelligence, an increasing number of work tasks can also be accomplished by technology in services and professional work (Huang and Rust, 2018). This process is speeded up the use of other digital technologies, of increased connectivity and big data and the rising platform economy. Thus, there are immense opportunities for digital innovation in services industries. Faced with COVID19 , there is also an instant executive focus on digital innovation that enables organizations to reset their innovative infrastructure and capacity (Dahlander and Wallin, 2020).

However, while digitalization can be seen as pure progress, it can also come with unintended consequences and certain side effects. For example, authors have predicted substantial shifts in the future of work, with rising unemployment rates and deepening divides between groups in society (Kim et al., 2017; Frey and Osborne, 2013; Brynjolfsson and McAfee, 2014; Chernoff and Warman, 2020). Kim et al. (2017) state that "Recent technological advances in big data, machine learning and robotics, have begun to have a negative influence on existing employment opportunities for human beings" (p. 1). Chernoff and Warman (2020) conclude that, as a result of COVID-19 and the risk of being infected with COVID-19 in connection with 
work, automation affects women twice as often as it affects men. Thus, women are being particularly exposed both to the risk of losing their job to automation and to contracting the disease. It is, therefore, important not only to look at how organizations mitigate the crisis through business model responses and digital innovation but also to put these into perspective and look for shifts to the digital trajectory overall.

\section{Method - our research departure}

This paper addresses responses to the COVID-19 outbreak through studying the abilities and readiness for digital business model responses in service industries (Kronblad, 2020; Brynjolfsson and McAfee, 2014) and retail (Ferreira et al., 2020; Berggren et al., 2020). We chose these industries, as our previous research focus on service industries (examples of publications, hidden to enable double blind review) and retail (example of publication, hidden to enable double blind review) has given us insights on challenges and opportunities in transformation in general (Pasmore, 2015; Johansen, 2017) and in digital transformation in particular (Kronblad and Pregmark, 2019; Reis et al., 2018; Kaufman and Horton, 2015). These insights led us to believe that these industries would yield examples that it would be interesting to find and to learn from.

To explore different responses to the COVID-19 distress to date and possibly in the future, we have collected recent examples of how organizations respond to COVID-19 through digital business model innovation, and we discuss what organizations can learn from this. In addition, we predict some paths for the development moving forward.

We consider this research to be phenomenon-driven (Schwarz and Stensaker, 2016) and strive to understand a practical problem without the constraint of a specific theoretical lens. Rather, we are using knowledge from a number of fields, such as research around digitalization (Kronblad and Pregmark, 2019; Reis et al., 2018; Kaufman and Horton, 2015), business model innovation (Björkdahl, 2009; Teece and Linden, 2017) and transformation/ change (Kotter, 2008; Pasmore et al., 2019). Moreover, as the pandemic is far from over as we write this paper, it is hard to claim any clear answers and conclusions regarding a topic like digital transformation. Digital transformation, like any substantial change process, takes time, and scholars often advise that it is better studied longitudinally (Pettigrew, 1997; Schein, 1987). This has, for obvious reasons, not been possible when collecting data for this paper. We will continue to study the long-term effects but argue that it is also important to continuously extract knowledge from this crisis that could be of use for organizations. That is why we have conducted this study, which we see as a result of an exploratory approach (Stebbins, 2001), and the paper will, therefore, end with ideas and reflections, rather than conclusions.

We have chosen a qualitative study, which is often discussed as appropriate for exploratory work (Stebbins, 2001) and also suitable for understanding a phenomenon in depth (Schwarz and Stensaker, 2016). Primary data have been collected in the form of interviews focusing on the effect of COVID-19 on business models and service offerings. We have interviewed professionals from the hotel, restaurant and travel industries (seven interviewees), retail (five interviewees) and public services (six interviewees). This means that this study focuses on service and retail. Consequently, it is important that we acknowledge that the result of our study is primarily applicable to these industries and should not automatically be transferred to other industries. A total of 18 interviews have been conducted, each lasting for approximately one hour. This is a fairly small sample, which is a limitation in this research. Moreover, we have primarily used convenience sampling within the industries described previously. These limitations indicate that the 
result of the study should be understood as indications of patterns, rather than as conclusive results.

Further, we have participated in six on-line seminars targeting the technological, economic and organizational consequences of COVID-19. In addition, we have looked though secondary sources such as newspapers, digital news and press releases to collect further examples of how organizations in service industries have responded to immediate COVID-19 distress with business model innovation. All data collection took place in the spring of 2020.

We (the authors of this paper) met for three full-day working sessions where we made sense of the data. Primary and secondary data were coded in emerging categories. This inductive data reduction process was inspired by Gioia et al. (2012), and after triangulating (Rothbauer, 2008) the findings through meetings with six of the interviewees, we had three categories of organizations (accelerators, crisispreneurs and endurers). These three categories emerged when we analyzed data focusing on business model responses. After going back to the literature (Moore and Tambini, 2018), however, we realized that an additional category might need a different type of digital response (of less magnitude), as they were born digital. After reviewing notes from seminars and conferences one more time, we identified one more category (thrivers). These organizations were often referred to as role models and/or their representatives were invited as keynote speakers at the conferences we attended.

\section{Findings: empirical examples of responses to COVID-19 distress}

Table 1 below briefly describes our findings with regard to how COVID-19 distress has been experienced in different industries and the ways in which organizations in these industries have coped with the COVID-19 outbreak. This list is not comprehensive; we certainly hope there are more good examples out there of organizations attempting to overcome (at least some of) the challenges they are currently facing as a result of COVID-19.

Table 1 shows examples of different responses to the COVID-19 distress in terms of switching to a more digital business model. When we analyzed the examples of digital transformation and innovation we found that they could be sorted into three types of business model innovation. Thus, we grouped the examples into three categories. We show how they represent different intensities in their business model innovation and connect this variation with three types of organizations (Table 2).

In the first category, we find examples of changes to consumption patterns, where parts of the service offering from the organizations are still grounded in materiality. The increase in take-out dinners from restaurants is a good example here. While restaurants implement digital tools for an efficient take-out process, the food is still a material product that needs to be transferred physically to be consumed. Other examples can be found in retail. One sales director in retail said: "We have created completely new partnerships. In a digital service people could collaborate on things from different companies and create efficient home delivery." We call the organizations that think creatively about how to add digital elements to their current material business models crisispreneurs.

The second category, accelerators, consists of examples where the business models have been completely transformed owing to the inclusion of new digital elements. One example here is a museum that offers virtual tours, turning the entire museum experience into a virtual one. Other good examples are the move toward virtual courtrooms, or the education system holding classes and exams digitally. One respondent, commenting on digitalization within the justice system, said: "We used to claim that we had to wait for the right trust toward digital tools from multiple stakeholders - and suddenly virtual courtrooms are 


\begin{tabular}{|c|c|c|c|}
\hline Industry & COVID-19 distress & $\begin{array}{l}\text { Examples of digital } \\
\text { transformation and innovation }\end{array}$ & $\begin{array}{l}\text { Responding to } \\
\text { the COVID-19 }\end{array}$ \\
\hline Retail & $\begin{array}{l}\text {-Extensive quarantines and social distancing } \\
\text { policies disable shopping in and in physical stores, } \\
\text { malls and supermarkets } \\
\text { - A general decrease in demand for durable goods } \\
\text { - Problems with global production/ supply chains }\end{array}$ & $\begin{array}{l}\text { - Internet shopping with home } \\
\text { delivery enabled by digital } \\
\text { platforms } \\
\text { - Customized opening hours }\end{array}$ & \\
\hline Culture & $\begin{array}{l}\text { - Extensive quarantines and social distancing } \\
\text { policies closes venues (theaters, movie theaters, } \\
\text { museums, sport arenas, etc.) } \\
\text { - Self-employed cultural workers experiencing } \\
\text { decreased demand }\end{array}$ & $\begin{array}{l}\text {-Museums offering virtual } \\
\text { tours } \\
\text { - Movie premieres being } \\
\text { released instantly at streaming } \\
\text { platforms } \\
\text { - Artist offering live concerts } \\
\text { over Facebook }\end{array}$ & \\
\hline $\begin{array}{l}\text { Hotels and } \\
\text { Restaurants }\end{array}$ & $\begin{array}{l}\text { - Extensive quarantines and social distancing } \\
\text { policies and closed borders prevents tourism and } \\
\text { rapidly disables hotels, restaurants and bars }\end{array}$ & $\begin{array}{l}\text {-Increased take-out offerings, } \\
\text { - Offerings to double the value } \\
\text { on gift-cards for later } \\
\text { consumption } \\
\text { - New policies promoting } \\
\text { outside dining } \\
\text { - Hotels being used for } \\
\text { temporary hospitals or } \\
\text { temporary housing for medical } \\
\text { staff }\end{array}$ & \\
\hline $\begin{array}{l}\text { Transportation } \\
\text { and Travel }\end{array}$ & $\begin{array}{l}\text { - Closed borders have resulted in a decreased } \\
\text { demand for cross border transportation of persons } \\
\text { and goods } \\
\text { - Travel industry with almost no travelers owing to } \\
\text { extensive quarantines and social distancing } \\
\text { policies } \\
\text { - Decreased demand public transport and taxi } \\
\text { services }\end{array}$ & $\begin{array}{l}\text {-Opportunities for driverless } \\
\text { transportation, } \\
\text { - Robot delivery of post } \\
\text { - Gift cards for later travel }\end{array}$ & \\
\hline $\begin{array}{l}\text { Public services/ } \\
\text { expert work }\end{array}$ & $\begin{array}{l}\text { - Continued or increased need of public services } \\
\text { such as social services, economic assistance, court } \\
\text { services } \\
\text { - Problematic delivery of services (although the } \\
\text { locations; courts, police stations, etc. are often } \\
\text { excluded from restrictions there is a prominent } \\
\text { risk of spreading the virus) }\end{array}$ & $\begin{array}{l}\text {-Digital services over platforms } \\
\text { or apps, } \\
\text { - Digital education } \\
\text { - Automated decision-making } \\
\text { - Virtual courtrooms }\end{array}$ & $\begin{array}{r}\text { Table } 1 . \\
\text { Coping with COVID- } \\
19 \text { distress }\end{array}$ \\
\hline
\end{tabular}

possible." The organizations that show these radical examples of digital business model innovation were already on a digital trajectory, but COVID-19 has caused their transformation to speed up.

The third group of examples are tightly bound to materiality and limited as regards digital transformation. These examples, such as offering to double the value on gift cards, do not change any crucial elements to the current business model, but primarily represent a way to increase instant cash flow to survive during the period of COVID-19 distress. These organizations are bound to materiality to the extent that digital innovation is not an option for them; they simply need to endure.

This means that we can identify three different types of organizations:

(1) Those whose main value propositions are intact (but fundamentally challenged), where the crisis has forced them to take entrepreneurial action, and digital 
JSTPM

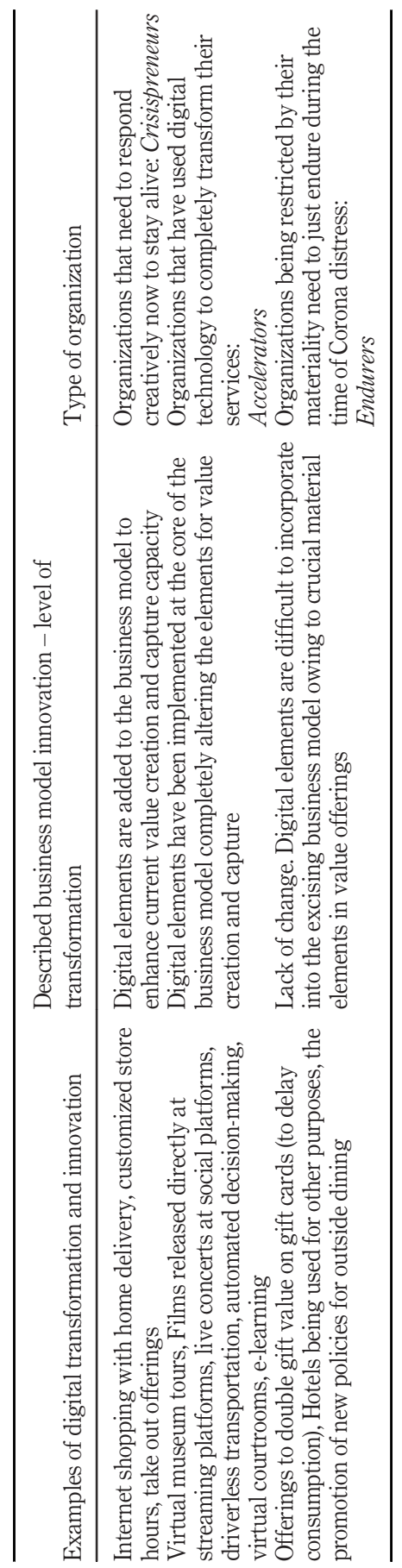

Table 2.

Level of business

model innovation and types of organizations 
initiatives are designed to boost (temporary) sales (crisispreneurs). Examples of these organizations can be found in the restaurant business and retail.

(2) Those who were already on a digital transformation trajectory (having a mainly immaterial output) but moving slowly. These organizations (accelerators) now seem to have accelerated their efforts and are no longer waiting to go digital with their offers. Examples can be found in public services (such as education) or expert work (such as law firms).

(3) Those where digital initiatives cannot offer much relief (endurers). These include the aviation industry and the hotel industry which are suffering from the immediate and devastating effects of COVID-19 on travel.

(4) An additional category (identified through literature and our attendance at seminars and conferences targeting COVID-19 and digitalization and not from the findings in Table 2), consists of the organizations who were mainly digitalized before the COVID-19 crisis and are not as challenged by the situation (thrivers). These companies can be found in, for example, on-line gaming and digital broadcasting. We have also described the basis of these organizations in our theoretical frame.

Our findings suggest the emergence of a "new normal." When asked to reflect upon whether their innovative digital business offerings and ways of working would last after the COVID19 crisis, 14 out of 18 of our interviewees expressed the view that their digital ways of working and doing business were here to stay. One declared:

'I now consider us a virtual organization. When Corona is over, we will still have digital offers and use digital tools to connect - it is just that we will meet occasionally. This is a fundamental shift for us. It has been coming for years but now it has happened, and there is no way back.'

Two respondents (both in retail) were not sure if they agreed with this (the lasting effects) but expected that most things would "more or less go back to normal." However, most interviewees said that they had experienced an effect on the overall digital capability of their organizations and speculated that more digital innovation and development might come in the future. A university professor said

'We will expect so much more from everyone when it comes to handling teaching and other things digitally. I think this is huge, and we could potentially innovate so much more regarding our value proposition. Maybe we can educate more people, maybe we can share more resources with world class institutions. This will change a lot of things and put a certain amount of pressure on us, on the way we work.'

Lasting effects from rapidly implemented solutions were also discussed at the various digital conferences. At a Harvard Law School seminar in relation to virtual courts:

'We are doing things we have never done before because we have no choice. But I think that a fair amount of this works fairly well, and when this ends we will not be going back to where we were on March 1st.'

At another conference, the CEO of a bank said: "We will never go back, we are forever changed. We are now primarily a virtual organization."

These comments indicate that leaders consider their digital responses to COVID-19 distress to be a fundamental shift. Although we have not seen the real consequences yet, data indicate that digital solutions have already impacted capabilities as well as processes and value propositions. 


\section{Discussion}

Our findings suggest that there are four types of organizations that differ in the material/ immaterial domain and, therefore, face different challenges and respond differently to COVID-19. Moreover, the data in this study suggest that many of the innovative/ entrepreneurial digital initiatives taken during the COVID-19 pandemic are expected to have lasting effects. Interviewees attribute these expectations both to the newly earned digital organizational capabilities and to the changes made in the organizational system. Previous research has also concluded that entrepreneurial/innovative initiatives can have a lasting effect on the organizational system (O'Connor, 2008; Fredberg and Pregmark, 2018; Shibata et al., 2019).

To answer our research question, we, therefore, first discuss to what extent the different types of organizations that we have identified create responses that will have lasting effects for the digital transformation. Second, hypothesizing that digital initiatives have enduring effects on how organizations work, organize and do business, we discuss the impact on their digital transformation trajectory. These digital transformation trajectories potentially provide organizations with opportunities to build digital capabilities with both short-term and long-term consequences. We, therefore, also suggest a number of ways that public actors and policymakers can view these categories and engage with them.

- Thrivers: these organizations are fully digitalized in terms of their business model, including a digital delivery of the service. Google and Netflix are examples of this category. Many of these organizations - although not directly affected - may play an important role during this COVID-19 pandemic. Also, several of these companies have responded to the crisis by enabling remote work and have, in fact, found it so beneficial that they plan not to return to the workplace, as it was once the crisis is over (Hadden et al., 2020). These organizations, which include Facebook and other social media platforms (Moore and Tambini, 2018), often have substantial coverage on a global scale and their digital models allow for exponential outreach (Bonchek, 2013). Governments could ask these organizations to work as their allies during the pandemic. Smart collaboration - and making use of good ideas from these thrivers may become a strong force in fighting and recovering from the crisis. Consequently, the internal business policy within these organizations might need to be adapted to be able respond to such requests.

- Accelerators: many of these organizations could have transformed before the crisis, but lacked a sense of urgency (Kotter, 2008). For these organizations, COVID-19 offers a window of opportunity to respond to the rising demands of the contemporary world (Pasmore et al., 2019). For example, digital ideas for the public sector, such as virtual courtrooms, have previously been subject to uncertainty (as regards public trust and acceptance) (Susskind, 2019), but it now seems that the public, faced with a potential spread of the virus, are more than willing to try out digital initiatives. It is important for both governmental and business policymakers to support the increased speed of these organizations by removing constraints while simultaneously ensuring the quality and security of the service. Also, although some of the digital initiatives that these organizations launch may be temporary, the digital capabilities they build and the learnings made seem to be here to last, forming a bridge to the long-term trajectory with a managerial focus and innovation infrastructure in place (Dahlander and Wallin, 2020). Moreover, in this type of organization we find examples of business model change/innovation (Hess et al., 2016; Kaufman and Horton, 2015) and system change (O'Connor, 2008), indicating a lasting effect. 
- Crisispreneurs: many organizations have managed to release entrepreneurial capability in the current crisis and have been creative in the development of digital value propositions. This newly found entrepreneurial capability could prove to be a success factor, not only to overcome the crisis but also in the long run. Entrepreneurial work in established settings has previously been described as an important success factor for managing transformation (Fredberg and Pregmark, 2018). While some new offerings and digitalized products/services will probably vanish when the crisis is over, the learnings and capabilities will last. If these crisispreneurs manage to survive, their increased entrepreneurial capability should have lasting effects. Business policymakers and innovation practitioners, therefore, need to encourage ideas and execution during the crisis through allowing deviations from standards and processes. This is also in line with Dahlander and Wallin's (2020) reasoning that it might be beneficial to set aside concerns about ownership of intellectual property and embrace new partners and processes for collaboration. Also, the organizations might be wise to put processes in place to capture current learnings and keep the new digital capabilities; they might be needed when the sense of urgency (Kotter, 2008) from the crisis is no longer a driving force for change and innovation.

- Endurers: these organizations - manifested by airlines and hotels, among others have little chance of innovating themselves out of this crisis. Because the core of their business model and value proposition (Osterwalder, 2011) is dependent on physical meetings and physical movements, the chances that digital solutions would be enough to save them are slim. These organizations will most likely need substantial governmental support to endure the crisis.

Figure 1 symbolizes an overview of the development in each of these categories in terms of short-term and long-term effects on the speed of digital transformation.

Based on the data, it appears that the major lasting increase in digital transformation effects comes from accelerators. All the interviewees, as well as comments from this type of organization in digital conferences, anticipate major changes in digital processes, value propositions and the organizational system as a whole. They also claim that the digital capabilities have improved dramatically. Considering previous research claiming that

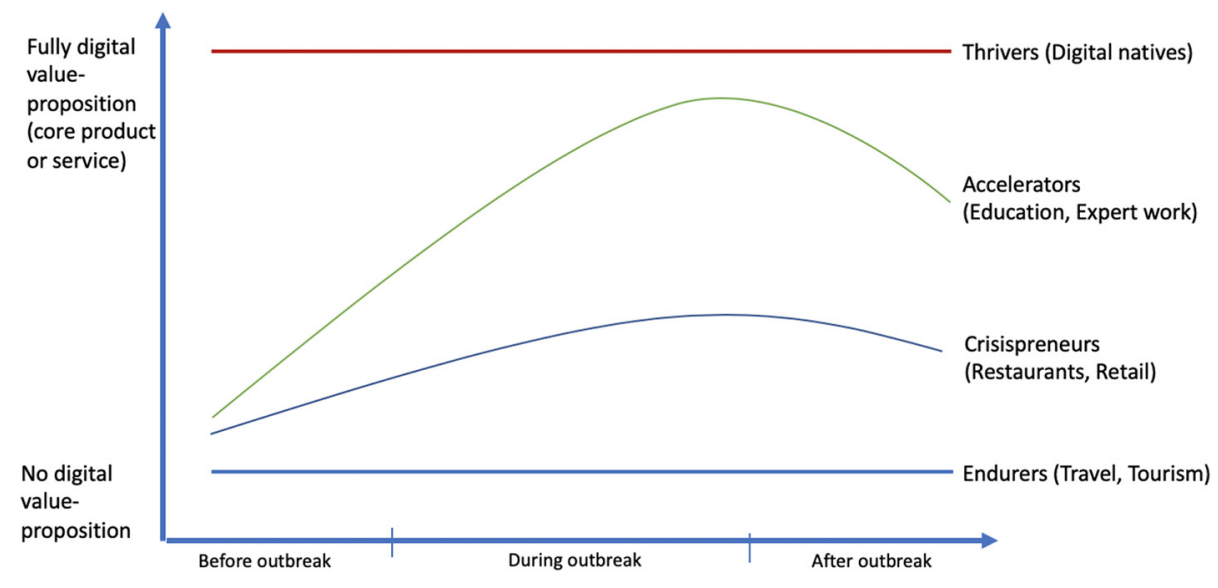

Responding to the COVID-19 crisis

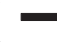


lasting effects need to be incorporated in the system (Kaufman and Horton, 2015; Fredberg and Pregmark, 2018) and that learning and development of new capabilities are crucial to develop such change (Worley and Mohrman, 2016; Kronblad and Pregmark, 2019). Also, crisispreneurs expect lasting effects, as some of their entrepreneurial initiatives seem to be valuable in terms of both efficiency and value creation. However, the data does not show evidence of system change and/or complete business model change to the same extent. Therefore, we argue that some of the digital COVID-19 effects are likely to disappear once the immediate urgency (Kotter, 2008; Beckhard and Harris, 1987) is not there to push the changes forward.

This paper suggests that there is tremendous potential for organizations to adopt more digital business models. Not only might digital business models become a means for shortterm survival, they might also support exponential growth (Bonchek, 2013) and create an innovation infrastructure for more and lasting value (Dahlander and Wallin, 2020). Authors have long called for organizations to increase innovation (Kodama and Shibata, 2014), entrepreneurial activity (Bartunek and Woodman, 2014) and agility (Worley and Mohrman, 2016). The data in this study suggest that all those types of activities seem to have exploded owing to the crisis, confirming and extending findings from, among others, livari et al. (2020) regarding transformation of education, Hadden et al. (2020) discussing remote work, and Kronblad and Pregmark (2021, forthcoming) about digital transformation in professional advisory firms. This digital explosion has the potential for positive effects for society. However, we argue that it is also important to recognize potential negative effects. If our digital journey continues to increase in speed, from the current elevated position, there will be some implications for policymakers to consider. This might mean that necessary competences will shift rapidly (Johansen, 2017; Kronblad and Pregmark, 2019), which has implications for education (to ensure the building of the correct competences) and for programs to re-train employees (whose capabilities are no longer needed). Furthermore, it is not only a question of balancing competences or capabilities, but it needs to be recognized that digital business models generally build less on human capital than do traditional models. Even though a digital transformation might enable organizations to survive the crisis and build new value, the new digital organizations would employ fewer people than previously and lead to a rapid increase in unemployment (Kim et al., 2017; Frey and Osborne, 2013). Frey and Osborne (2013) predicted that unemployment would increase in almost half of the investigated occupations owing to digital advances. Chernoff and Warman (2020) show that COVID-19 has indeed led to such effects, with the level of automation of work accelerating during the crisis. As a result, perhaps both unemployment rates and bankruptcies will be the next relevant curves to flatten out.

\section{Contribution}

In this paper, we show that different categories of organizations that experience the same external shock and sense of urgency from COVID-19 have vastly different alternatives for acting on digital opportunities through business model responses. This contributes to the literature that discusses the digital transformation of different industries (Kronblad, 2020; Schuchmann and Seufert, 2015), by showing the relevance of focusing on different categories of organizations and their features (materiality/immateriality) rather than on the industries per se. For example, whereas COVID-19 has had a strong negative impact on tourism, different types of organizations within this domain can respond to the changes in different ways. We show that hotels, museums and restaurants, for example, fall into different categories of organizations that depend on material/immaterial aspects of their current business models, and how viable digital business models innovations are for them. 
Thus, discussing the four categories that we identified can be of interest both for the understanding of digital opportunities in organizations and to understand the digital trajectory for society and whether the current shift will last. However, further research needs to be completed to extend the understanding and implications for the organizations in each of the categories.

This paper shows that for some types of organizations (particularly crisispreneurs and accelerators), digital business model innovation can be a key way to mitigate immediate COVID19 effects and become fit for the future. This paper thereby contributes to literature on digital business model innovation (Nambisan et al., 2017) by showing how sudden external shocks can inspire innovation and entrepreneurship among certain types of organizations. It also draws attention to the importance of understanding the starting point for different organizations heading toward transformation, as it shows that the different starting points, in regard to business models, affect the viable responses in each of the categories. This suggests that digitalization and digital opportunities need to be mapped against material/immaterial aspects of current business models (Osterwalder, 2011) to spot what digital innovation would be applicable.

This study shows that organizations that were already on a digital route but not yet thriving (accelerators) appear to be the ones anticipating that both their newly acquired capabilities and their recently developed models for work and business will last. This indicates that this category of organization is inducing system change (Beer, 2009) owing to digital innovation. This realization contributes to literature on transformation and change (Beer, 2009; Pasmore, 2015; Fredberg and Pregmark, 2016), through suggesting a clear link between the ability to continuously adapt (Reeves and Deimler, 2011; Pasmore et al., 2019) and system change (Beer, 2009; O'Connor, 2008). We further argue that in a fast-changing world (Johansen, 2017), organizations need to change continuously (Pasmore, 2015) and radically (Johansen, 2017) and that organizations cannot rely on external shocks and crises to create the necessary sense of urgency (Kotter, 2008). Instead, the organizational system needs to be constantly ready to innovate and change. This paper suggests a classification of organizations to understand their readiness for such change.

This paper also provides a practical contribution by showing actors in service and retail industries how other organizations have mitigated their COVID-19 distress and re-designed their business models with new digital elements. Leaders and policymakers could benefit from reflecting upon which category they might be in, how to prepare for various scenarios, and for a potential shift toward another category that will make the organization more resilient toward the digital winds of change. Also, leaders and policymakers need to reflect on the readiness for these changes in society, as there is a digital divide between citizens to reflect upon. While this is a minor issue in retail, it is certainly an issue in public services, where it is important that digital transformation efforts increase accessibility and efficiency for the services provided (Iivari et al., 2020). Although this paper has focused on digital innovation, it may also be of interest for practitioners to reflect on whether these categories are applicable for other types of innovation.

An additional contribution of this paper is the message to public policymakers in anticipating that a rapid change from human to artificial intelligence and from human capital to technological and structural capital will also entail rising unemployment. This must be dealt with in order for this accelerated digital transformation to be sustainable for society at large.

\section{Future directions}

We would encourage more research discussing different factors that are important for how organizations can respond to change. Moreover, we also hope that future discussions will 
include further investigations based on the categories that we have found. We believe that it would be beneficial to further investigate how organizational policymakers and leaders can prepare for external shocks and for digitalization through identifying themselves in the category framework suggested in this paper. We sincerely hope that COVID-19 is not here to stay, but digitalization undoubtedly is. The digital strategies might need to vary depending on the category. In addition, we believe that some corner stone organizations in society (for example, transportation) might end up as endurers. Government policymakers might need to consider how to prepare these organizations for a new era and develop policies for support. This needs further investigation.

Several scholars agree that COVID-19 has affected the speed of digitalization in firms (Kudyba, 2020; Leonardi, 2020; Iivari et al., 2020), which means that the accumulated speed of digital transformation in society is also increasing. We believe that COVID-19 will, in all likelihood, result in a more rapid digital transformation in society than previously expected. Consistent with findings by Kudyba (2020), we expect a COVID-19 hump - with a sharp and sudden increase in digitalization - in the digital trajectory, owing to the current pandemic and immediate organizational responses (primarily from crisispreneurs and accelerators). Although some of their digital initiatives will only last in the short term, newly gained digital capabilities in these organizations will likely remain, which will accelerate the curve and the rate of the digital transformation. This assumption builds on previous research that suggests that entrepreneurial/innovative work has an enduring effect on organizations (Kodama and Shibata, 2014; O'Connor, 2008; Pasmore, 2015; Fredberg and Pregmark, 2018; Dahlander and Wallin, 2020). Moreover, Reis et al. (2018) discuss how digital transformation can reach different levels depending on whether digitalization is related to internal processes, external propositions or business models. The data in this study show that many organizations have digitalization initiatives that affect all levels. Moreover, many of the leaders interviewed explain that they foresee lasting effects in the whole system, from the way they organize and the way they do business to their business models. Thus, they expect to have built digital capabilities into the system. How such substantial lasting effects and a shift in digital trajectory will affect society needs further investigation.

We hope that more researchers will join in this endeavor and help build knowledge on how digital innovation can be used to open up secure and virus-free patterns for value creation, and how digital opportunities can be captured to prevail - as organizations and as society.

\section{References}

Bartunek, J. and Woodman, R.W. (2014), "Beyond Lewin: toward a temporal approximation of organization development and change", Annual Review of Organizational Psychology and Organizational Behavior, Vol. 2 No. 1, pp. 157-182.

Beckhard, R. and Harris, R.T. (1987), Organizational Transitions: Managing Complex Change, 2nd ed., Addison-Wesley, Reading, MA.

Beer, M. (2009), High Commitment, High Performance: How to Build a Resilient Organization for Sustained Advantage, Jossey-Bass, San Francisco, CA.

Berggren, R., Pregmark, J.E., Fredberg, T. and Frössevi, B. (2020), “Change in tightly coupled systems: middle manager role and action", Research on Organization Change and Development, Vol. 28.

Berman, S.J. (2012), "Digital transformation: opportunities to create new business models", Strategy and Leadership, Vol. 40 No. 2, pp. 16-24, doi: 10.1108/10878571211209314.

Björkdahl, J. (2009), "Technology cross-fertilization and the business model: the case of integrating ICTs in mechanical engineering products", Research Policy, Vol. 38 No. 9, pp. 1468-1477. 
Bonchek, M. (2013), "Purpose is good", Shared Purpose is Better. Harvard Business Review, March, Vol. 14.

Brynjolfsson, E. and McAfee, A. (2014), The Second Machine Age: Work, Progress, and Prosperity in a Time of Brilliant Technologies, W. W. Norton \& Company, New york, NY.

Responding to the COVID-19 crisis

Chernoff, A.W. and Warman, C. (2020), COVID-19 and Implications for Automation (No. w27249), National Bureau of Economic Research.

Dahlander, L. and Wallin, M. (2020), "Why now is the time for 'open innovation”, Harvard Business Review, June 5, available at: https://hbr.org/2020/06/why-now-is-the-time-for-open-innovation

Ferreira, M.J., Moreira, F., Pereira, C.S. and Durão, N. (2020), "The digital transformation at organizations - the case of retail sector", in Rocha, Á., Adeli, H., Reis, L., Costanzo, S., Orovic, I. and Moreira, F. (Eds), Trends and Innovations in Information Systems and Technologies. WorldCIST 2020. Advances in Intelligent Systems and Computing, Vol. 1159, Springer, Cham, doi: 10.1007/978-3-030-45688-7_56.

Fitzgerald, M., Kruschwitz, N., Bonnet, D. and Welch, M. (2014), "Embracing digital technology: a new strategic imperative", MIT Sloan Management Review, Vol. 55 No. 2, pp. 1-12.

Fredberg, T. and Pregmark, J. (2016), "Transformation in a tightly nested system: employing fast cycles of change", Research on Organization Change and Development, Vol. 24, pp. 185-219.

Fredberg, T. and Pregmark, J.E. (2018), "Organization renewal through corporate entrepreneurship: when the seed changes the soil", Research on Organization Change and Development, Vol. 26, Emerald, Bingley, UK.

Frey, C.B. and Osborne, M.A. (2013), "The future of employment: how susceptible are jobs to computerisation?", Technological Forecasting and Social Change, Vol. 114, pp. 254-280.

Gioia, D.A., Corley, K.G. and Hamilton, A.L. (2012), "Seeking qualitative rigor in inductive research: notes on the Gioia methodology", Organizational Research Methods, Vol. 16 No. 1, pp. 15-31.

Hadden, J. Cassado, L. Sonnemaker, T. and Borden, T. (2020), "20 major companies that have announced employees can work remotely long term business insider retrieved Nov. 29", available at: www.businessinsider.com/companies-asking-employees-to-work-from-home-dueto-coronavirus-2020? $\mathrm{r}=\mathrm{US} \& \mathrm{IR}=\mathrm{T}$

Hess, T., Matt, C., Benlian, A. and WiesböCk, F. (2016), "Options for formulating a digital transformation strategy", MIS Quarterly Exclusive, Vol. 15 No. 2.

Huang, M.H. and Rust, R.T. (2018), "Artificial intelligence in service”, Journal of Service Research, Vol. 21 No. 2, pp. 155-172.

Iivari, N., Sharma, S. and Ventä-Olkkonen, L. (2020), "Digital transformation of everyday life - how COVID-19 pandemic transformed the basic education of the young generation and why information management research should care", International Journal of Information Management, Vol. 55, p. 102183.

Johansen, B. (2017), The New Leadership Literacies: Thriving in a Future of Extreme Disruption and Distributed Everything, Berrett-Koehler Publishers.

Kaufman, I. and Horton, C. (2015), "Digital transformation: leveraging digital technology with core values to achieve sustainable business goals", The European Financial Review (DecemberJanuary), pp. 63-66.

Kim, Y.J., Kim, K. and Lee, S. (2017), "The rise of technological unemployment and its implications on the future macroeconomic landscape", Futures, Vol. 87, pp. 1-9.

Kodama, M. and Shibata, T. (2014), "Strategy transformation by strategic innovation", R\&D Management, Vol. 44 No. 1, pp. 75-103, doi: 10.1111/radm.12041.

Kotter, J.P. (2008), A Sense of Urgency, Harvard Business Press, Boston, MA.

Kronblad, C. (2020), "How digitalization changes our understanding of professional service firms", Academy of Management Discoveries, Published Online: 27 Apr 2020. 
Kronblad, C. and Pregmark, J.E. (2019), "Beyond digital inventions - diffusion of technology and organizational capabilities to change", in Corrales, M., Fenwick, M. and Haapio, H. (Eds), Legal Tech, Smart Contracts and Blockchain, Springer Singapore, Singapore, pp. 123-146.

Kronblad, C. and Pregmark, J.E. (2021), How Covid-19 Has Changed the Digital Trajectory for Professional Advisory Firms, COVID-19 and the Future of the Service Industry Post-Pandemic: Insights and Resources, Springer.

Kudyba, S. (2020), "COVID-19 and the acceleration of digital transformation and the future of work", Information Systems Management, Vol. 37 No. 4, pp. 284-287, doi: 10.1080/10580530.2020.1818903.

Leonardi, P.M. (2020), "COVID-19 and the new technologies of organizing: digital exhaust, digital footprints, and artificial intelligence in the wake of remote work", Journal of Management Studies, Vol. 58 No. 1, doi: 10.1111/joms.12648.

Moore, M. and Tambini, D. (2018), Digital Dominance: The Power of Google, Amazon, Facebook, and Apple, Oxford University Press, New York, NY.

Nambisan, S., Lyytinen, K., Majchrzak, A. and Song, M. (2017), "Digital innovation management: reinventing innovation management research in a digital world", MIS Quarterly, Vol. 41 No. 1.

O'Connor, G.C. (2008), "Major innovation as a dynamic capability: a systems approach", Journal of Product Innovation Management, Vol. 25 No. 4, pp. 313-330.

Osterwalder, A. (2011), "Business model generation", available at: http://alexosterwalder.com/books.html

Pasmore, W.A. (2015), Leading Continuous Change: Navigating Churn in the Real World, BerrettKoehler, Oakland, CA.

Pasmore, W., Winby, S., Mohrman, S.A. and Vanasse, R. (2019), "Reflections: sociotechnical systems design and organization change", Journal of Change Management, Vol. 19 No. 2, pp. 67-85, doi: 10.1080/14697017.2018.1553761.

Pettigrew, A.M. (1997), "What is a processual analysis?”, Scandinavian Journal of Management, Vol. 13 No. 4, pp. 337-348, doi: 10.1016/S0956-5221(97)00020-1.

Reeves, M. and Deimler, M. (2011), "Adaptability: the new competitive advantage”, Harvard Business Review, July-August, 2011, available at: https://hbr.org/2011/07/adaptability-the-newcompetitive-advantage

Reis, J., Amorim, M., Melão, N. and Matos, P. (2018), "Digital transformation: a literature review and guidelines for future research", in Rocha, Á., Adeli, H., Reis, L.P. and Costanzo, S. (Eds), Trends and Advances in Information Systems and Technologies. Advances in Intelligent Systems and Computing, Vol. 745, Springer, Cham.

Remane, G., Hanelt, A., Nickerson Robert, C. and Kolbe Lutz, M. (2017), "Discovering digital business models in traditional industries", Journal of Business Strategy, Vol. 38 No. 2, pp. 41-51, doi: 10.1108/JBS-10-2016-0127.

Rogers, E. (1962), Diffusion of Innovations, 1st ed., Free Press of Glencoe, New York, NY.

Ross, J., Sebastian, I. and Beath, C. (2017), "How to develop a great digital strategy", MIT Sloan Management Review, Vol. 58 No. 2, pp. 7-9.

Rothbauer, P. (2008), "Triangulation”, in Given, L. (Ed.), The SAGE Encyclopedia of Qualitative Research Methods, Sage, pp. 892-894.

Schein, E.H. (1987), The Clinical Perspective in Fieldwork, Vol. 5, SAGE, Thousand Oaks, CA.

Schuchmann, D. and Seufert, S. (2015), "Corporate learning in times of digital transformation: a conceptual framework and service portfolio for the learning function in banking organisations", International Journal of Advanced Corporate Learning (IJAC)), Vol. 8 No. 1, pp. 31-39.

Schwarz, G. and Stensaker, I. (2016), "Showcasing phenomenon-driven research on organizational change".

Shibata, T., Baba, Y., Kodama, M. and Suzuki, J. (2019), "Managing ambidextrous organizations for corporate transformation: a case study of Fujifilm”, R\&D Management, Vol. 49 No. 4, pp. 455-469, doi: $10.1111 /$ radm.12326. 
Stebbins, R.A. (2001), Exploratory Research in the Social Sciences, Sage, Thousand Oaks, CA. Susskind, R.E. (2019), Online Courts and the Future of Justice, Oxford University Press, Great Brittain.

Teece, D.J. and Linden, G. (2017), "Business models, value capture, and the digital enterprise", Journal of Organization Design, Vol. 6 No. 1, p. 8, doi: 10.1186/s41469-017-0018-x.

Responding to the COVID-19 crisis

Utterback, J.-M. and Abernathy, W.-J. (1975), “A dynamic model of process and product innovation”, Omega, Vol. 3 No. 6, pp. 639-656.

Worley, C. and Mohrman, S. (2016), "A new view of organization development and change competencies: the engage and learn model", in Jamieson, D.W., Barnett, R.-C. and Buono, A.F. (Eds), Consultation for Organizational Change Revisited, Information Age Publishing, Charlotte, NC, pp. 29-48.

\begin{abstract}
About the authors
Charlotta Kronblad is a $\mathrm{PhD}$ candidate at Chalmers University of Technology. Her research focuses on digital transformation and targets the intersections of business and law and professional and organizational change. In parallel she is working as an advisor and keynote speaker. Before switching to an academic career, Charlotta practiced law for a decade. Her first-hand experience of the digital transformation of the legal industry is what awoke her interest to study this phenomenon.

Johanna Envall Pregmark has a PhD from Chalmers University of Technology, where she is a researcher of organizational transformation and innovation. In parallel, she is working as a Consultant at TruePoint as well as keynote speaker. Prior to her doctoral studies, she worked as a Management Consultant for 15 years and was a partner at a major Swedish consultancy firm. She was also part of forming an international alliance of consultancy firms, with transformation and renewal as focus. Apart from working with action research issues in transforming industries, she is part of the core team that drives Center for Higher Ambition Leadership Europe and a Corporate Entrepreneurship Master Education at Chalmers School of Entrepreneurship. Johanna Envall Pregmark is the corresponding author and can be contacted at: pregmark@chalmers.se
\end{abstract}

For instructions on how to order reprints of this article, please visit our website: www.emeraldgrouppublishing.com/licensing/reprints.htm Or contact us for further details: permissions@emeraldinsight.com 